\title{
Perubahan Socio-Culture dan Economic Separation Keluarga dan Pengaruhnya terhadap Kehidupan Lansia di Desa Tileng Kecamatan Girisubo
}

\author{
Sudrajat $^{1}$, Wiwik Puji Mulyani ${ }^{2}$ dan Ahmad Saikhu ${ }^{3}$
}

${ }^{123}$ Departemen Geografi Lingkungan, Fakultas Geografi, Universitas Gadjah Mada, Indonesia

Email Koresponden: sdarajat@ugm.ac.id

Diterima: 2018-11-24 /Refisi: 2019-12-22 Disetujui: 2019-03-21

(๑2019 Fakultas Geografi UGM dan Ikatan Geograf Indonesia (IGI)

\begin{abstract}
Abstrak Di satu sisi migrasi penduduk dari desa ke kota telah mampu merubah nilai socio-culture dan sistem ekonomi keluarga, namun di sisi lain telah menyebabkan lansia hidup terpisah dari anggota keluarganya. Berdasarkan hal tersebut maka penelitian ini dilakukan dengan tujuan untuk; (1) mengkaji proses perubahan socio-culture dan economic separation yang terjadi pada keluarga lansia; (2) menganalisis kondisi kehidupan sosial-demografi dan ekonomi lansia dalam kondisi spatial separation; dan (3) menganalisis pengaruh perubahan socio-culture dan economic separation terhadap kehidupan lansia. Penelitian ini dilakukan di Desa Tileng Kecamatan Girisubo dengan mengambil sampel keluarga lansia. Sampel diambil secara random sampling. Data primer dikumpulkan melalui wawancara terstruktur, sedangkan data sekunder dikumpulkan dari instatsi pemerintah. Data disajikan dalam bentuk tabel frekuensi dan tabel silang, kemudian dianalisis secara deskripssi kualitatif. Hasil penelitian menemukan bahwa proses perubahan socio-culture diawali dari proses perubahan pendidikan anggota keluarga dan perubahan padangan lansia terhadap nilai-nilai socio-culture, sedangkan proses economic separation diawali dari proses perubahan aktivitas ekonomi tradsional menjadi ekonomi modern pada keluarga lansia. Penelitian ini juga menemukan kondisi kehidupan lansia yang tercemin dari kondisi sosial-demografi dan ekonomi dalam kondisi spatial separation cukup beragam. Temuan lain dari penelitian ini adalah perubahan socio-culture dan economic separation pada keluarga lansai berpengaruh terhadap kondisi kehidupan lansia yang terpisah dari anggota keluargnya.
\end{abstract}

Kata kunci: lansia; socio-culture; economic separation; spatial separation

\begin{abstract}
On one side population migration from village to city has been able to change socio-culture values and the family's economic system, but on the other hand has caused the elderly to live separately from their family members. Based on this, the research was conducted with the aim of; (1) reviewing the process of socio-culture change and economic separation that occurs in elderly family; (2) analyze the socio-demographic and economic conditions of the elderly in spatial separation conditions; and (3) analyze the influence of socio-culture changes and economic separation on the lives of the elderly. This research was conducted in Tileng Village, Girisubo District by taking a sample of elderly family. The sample is taken by random sampling. Primary data is collected through structured interviews, while secondary data is collected from government institutions. Data is presented in the form of frequency tables and cross tables, then analyzed qualitatively. The results of the study found that the process of socio-culture change begins with the process of changing the education of family members and changes in the views of the elderly towards socio-culture values, while the economic separation process beginning with the process of changing traditional economic activities into a modern economy in elderly family. This study also found the living conditions of the elderly reflected in socio-demographic and economic conditions in spatial separation conditions are quite diverse. Other findings from this study are socio-culture changes and economic separation in elderly family influence on living conditions of the elderly who are separated from their family members.
\end{abstract}

Keywords: elderly; socio-culture; economic separation; spatial separation

\section{PENDAHULUAN}

Keberhasilan pembangunan kualitas sumber daya manusia di bidang kependudukan tercermin dari adanya peningkatan pendidikan, kesehatan dan ratarata angka harapan hidup di setiap kabupaten maupun propinsi (Ningrum, 2017; Yuliani \& Saragih, 2014). Namun demikian, meningkatnya kesehatan dan angka harapan hidup tersebut telah memicu pertambahan jumlah penduduk lansia. Bahkan, diprediksi pertambahan jumlah penduduk lansia akan terus meningkat sejalan dengan meningkatnya perbaikan kesehatan dan gizi masyarakat (Kemenkes, 2018). Jika pada pada mulanya proporsi penduduk lansia di Indonesia relatif rendah yaitu sekitar 4,5\% tahun 1971 dan tahun 1990 menjadi 6,6\%, sedangkan pada tahun 2020 diprediksi akan naik menjadi 11 \% (BPS, 2016).

Penduduk Lansia menurut Peraturan Pemerintah Republik Indonesia Nomor 43 Tahun 2004 adalah seseorang yang telah mencapai usia 60 (enam puluh) tahun ke atas, sedangkan menurut Affandi (2009) seseorang disebut sebagai lansia jika telah berumur 60 tahun ke atas di negara berkembang atau 65 tahun 
ke atas di negara maju. Hal yang sama dikemukan Direktorat Jenderal Rehabilitasi Sosial (2013) bahwa lansia adalah seseorang baik wanita maupun laki-laki yang telah berusia 60 tahun ke atas. Sementara itu, menurut WHO (2003) lansia dapat diklasifikasikan menjadi beberapa kelompok yaitu lansia muda (middle age) berumur 45-59 tahun, lanjut usia (elderly) berumur 60-74 tahun, lanjut usia tua (old) berumur 75-90 tahun dan usia sangat tua (very old) berumur di atas 90 tahun.

Pertambahan jumlah penduduk lansia akan terasa lebih cepat lagi di beberapa wilayah di Indonasia yang memiliki rata-rata angka harapan hidup tinggi, seperti di Daerah Istimewa Yogyakarta. Pada tahun 2015 jumlah penduduk lansia di Daerah Istimewa Yogyakarta tercatat sebanyak 492.200 jiwa lansia, diantaranya sebanyak 132.311 jiwa atau sekita 26,9\% berdomisili di Kabupaten Gunungkidul (BPS, 2016). Peningkatan jumlah penduduk lansia disatu sisi akan berdampak positif, jika penduduk lansia berada dalam keadaan sehat, aktif dan produktif. Disisi lain akan berdampak negatif jika lansia memiliki masalah penurunan kesehatan yang berakibat pada peningkatan biaya pelayanan kesehatan, penurunan produtivitas kerja, penurunan pendapatan, peningkatan disabilitas, menurunya tingkat mobilitas, menurunya inteligensi, tidak adanya dukungan sosial dan lingkungan yang tidak ramah terhadap penduduk lansia (Kemenkes, 2017; Andini dkk., 2013). Fenomena tersebut akan menyebabkan munculnya pandangan bahwa lansia akan menjadi beban tanggungan penduduk produktif, terutama pada pemenuhan kebutuhan pokok hidupnya.

Selain itu, keberadaan pertambahan jumlah lansia juga dikaitkan angka rasio ketergantungan yang merupakan perbandingan antara penduduk usia produktifdengan pendudukusianon produktiftermasuk di dalamnya adalah lansia. Jika jumlah penduduk lansia semakin meningkat jumlahnya maka beban penduduk usia produktif akan semakin besar dalam menanggung non produktif termasuk penduduk lansia (BPS, 2010). Meningkatnya beban ketergantung lansia pada usia produktif telah menimbulkan berbagai permasalahan. Apalagi jika anggota keluarga telah bermigrasi ke kota dan menetap di daerah tujuan karena alasan ekonomi, sehingga banyak orang tua ditinggalkan di kampung halamannya (Arini, 2001; Sarmita dkk, 2014 \& Pepe dkk., 2014). Pada akhirnya fenomena tersebut memicu hubungan orang muda (anggota keluarga) dan orang tua (lansia) semakin renggang. Bahkan dengan akfivitas ekonomi modern yang penuh dengan kesibukan telah menyebabkan mereka hanya memiliki sedikit waktu untuk memikirkan lansia (orang tua) di kampung halamannya. Demikian juga, dengan adanya pergeseran perilaku sosial budaya masyarakat saat ini, yaitu anak yang telah berkeluarga segera memisahkan diri dari orang tuanya, sehingga menyebabkan komunikasi yang semakin berkurang antara orang tua dan anak, pemberian perawatan terhadap orang tua menurun dan kurangnya perhatian anak terhadap lansia (orang tua)
(Cowgill, 1986; Watson, 2003; Effendi \& Sukamdi, 1994).

Kurang perhatiannya anak terhadap lansia disebabkan karena adanya degradasi nilai-nilai socioculture masyarakat. Di mana degradasi nilai socioculture tersebut telah menyebabkan adanya pergeseran tanggung jawab keluarga untuk pemeliharaan orang tua (lansia). Salah satu contohnya pada masyarakat kelas menengah ke atas ada kecenderungan meningkatnya pergeseran dalam melakukan perawatan lansia dari keluarga beralih ke lembaga-lembaga berbayar (Panti Jompo). Dengan kata lain, sumber jaminan penduduk lansia nampaknya dialihkan dari sistem dukungan socio-culture keluarga ke sistem dukungan pemerintah atau dari perorangan ke lembaga pemerintah. Bahkan, dengan perubahan nilai-nilai socio-culture dalam keluarga, sering sekali para lansia kehilangan pertalian keluarga yang selama ini diharapkan, sehingga peran dan status lansia dalam keluarga semakin berkurang. Selain itu juga mulai terlihat hilangnya bentuk-bentuk dukungan keluarga terhadap lansia yang semakin menurun (Cowgil, 1986 \& Watson, 2003). Fenomena ini terjadi karena sebagian masyarakat menganggap bahwa lansia itu hanyalah beban keluarga karena lansia dianggap hanya mampu bergantung pada orang lain. Munculnya pergeseran nilai socio-culture dalam keluarga tentu akan membawa masalah tersendiri dalam penanganan lansia yang akan terus meningkat sejalan dengan meningkatnya jumlah lansia karena meningkatanya angka harapan hidup (Junaedi, 2007).

Menurut Badan Koordinasi Keluarga Berencana Nasional (1998) ada tiga aspek yang perlu dipertimbangkan dari penduduk lansia, yaitu aspek biologi, aspek ekonomi dan aspek social. Secara biologis penduduk lanjut usia adalah penduduk yang mengalami proses penuaan secara terus menerus, yang ditandai dengan menurunnya daya tahan fisik yaitu semakin rentannya terhadap serangan penyakit yang dapat menyebabkan kematian. Secara ekonomi, penduduk lanjut usia lebih dipandang sebagai beban dari pada sebagai sumber daya karena sudah tidak produktif. Banyak orang beranggapan bahwa kehidupan masa tua tidak lagi memberikan banyak manfaat, bahkan ada yang sampai beranggapan bahwa kehidupan masa tua, seringkali dipersepsikan secara negatif sebagai beban keluarga dan masyarakat. Sementara itu, dari aspek sosial penduduk lanjut usia merupakan satu kelompok sosial yang menduduki kelas sosial yang tinggi yang harus dihormati oleh warga muda. Akibatnya sering bertentangan dengan konsep anak modern yang hidup secara bebas.

Sejak awal kehidupan sampai berusia lanjut menurut Junaedi (2007) setiap manusia memiliki kebutuhan psikologis dasar yang harus terpenuhi seperti, rasa nyaman bagi dirinya sendiri dan rasa nyaman terhadap lingkungan yang ada. Oleh karena itu, cukup wajar jika kehidupan lansia di sisa hidupnya sangat membutuhkan perhatian dan perawatan dari orang lain. Bahkan kebutuhan dasar seperti, sandang, 
pangan dan papan menjadi bagian penting yang harus tetap terpenuhi dalam kehidupan lansia. Kebutuhan dasar lansia menurut Maslow (2007); Kartikasari (2012) \& Ninda (2017) dapat dikelompokan menjadi menjadi 5 (lima) kelompok yaitu; (1) kebutuhan fisik (physiological needs) adalah kebutuhan fisik atau biologis seperti pangan, sandang, papan, seks dan sebagainya; (2) kebutuhan ketentraman (safety needs) adalah kebutuhan akan rasa keamanan dan ketentraman, baik lahiriah maupun batiniah seperti kebutuhan akan jaminan hari tua, kebebasan, kemandirian dan sebagainya; (3) kebutuhan sosial (social needs) adalah kebutuhan untuk bermasyarakat atau berkomunikasi dengan manusia lain melalui paguyuban, organisasi profesi, kesenian, olah raga, kesamaan hobby dan sebagainya ; (4) Kebutuhan harga diri (esteem needs) adalah kebutuhan akan harga diri untuk diakui akan keberadaannya; dan (5) Kebutuhan aktualisasi diri (self actualization needs) adalah kebutuhan untuk mengungkapkan kemampuan fisik, rohani maupun daya pikir berdasarkan pengalaman masing-masing, bersemangat untuk hidup dan berperan dalam kehidupan. Untuk memenuhi semua kebutuhan dasar tersebut banyak lansia yang mengharapkan dukungan dan kedekatan hubungan antara lansia dengan anggota keluarga (anak-anaknya).

Dilematis kewajiban sebagai seorang anak menurut Junaedi (2007) di satu sisi anak merasa berkewajiban untuk lebih dekat dalam merawat lansia di sisa hari tuanya, namun di sisi lain anak harus bekerja untuk mencari nafkah yang menyebabkan jauh dari orang tuanya. Bahkan, dengan adanya pergeseran nilainilai social-budaya yang menyebabkan munculnya pemisahan anatara lansia dengan anggota keluarganya. Pemisahan tersebut merupakan salah satu dampak negatif dari pergeseran nilai-nilai sosial dalam keluarga lansia sehingga terjadi pemisahan struktur keluarga.

Pemisahan lansia dari struktur keluarga tersebut diantaranya adalah spatial separation, culture separation dan economic separation. Fenomena spatial separation dipicu oleh adanya peningkatan prevalensi migrasi desa-kota yang menyebabkan banyak penduduk lansia yang ditinggalkan oleh keluarganya. sehingga penduduk lansia tidak lagi dalam satu keluarga, sedangkan culture separation dipicu adanya keberhasilan pembangunan dalam peningkatan pendidikan wanita (Junaedi, 2007). Peningkatan pendidikan wanita menurut Ehrenberg \& Smith (1987) akan menyebabkan nilai waktu wanita di luar rumah akan lebih tinggi, sehingga alokasi waktu untuk mengurus orang tua semakin berkurang. Selain itu, peningkatan kemajuan komunikasi juga telah menyebabkan terjadi perbedaan nilai budaya yang cukup tajam antara penduduk muda dan lansia, sehingga akan kesulitan untuk menggabungkan keduanya dalam satu kehidupan luas.

Sementara itu, munculnya economic separation dipicu oleh adanya perubahan dari ekonomi tradisional ke ekonomi modern yang dilakukan generasi muda. Di mana peranan orang tua yang tinggi dalam aktivitas ekonomi tradisional akan berkurang dalam masyarakat modern. Hal ini disebabkan karena angkatan kerja muda dengan pendidikan lebih baik, akan lebih mampu menyesuaikan diri dengan teknologi baru dan akan mempunyai penghasilan yang lebih baik dari orang tuanya. Bahkan, dengan meningkatnya mobilitas vertikal telah menyebabkan perubahan sikap perilaku dan aspirasi mereka terhadap aspekaspek sosial budaya dan ekonomi (Junaedi, 2007). Akibat dari perubahan tersebut menurut Cowgill (986) menyebabkan berkurangnya rasa tanggung jawab untuk menyantuni keluarga pada usia lanjut. Demikian juga, dilihat dari segi ekonomi, ada kecenderungan bahwa keluarga sebagai a unit of production shared telah berubah yaitu, terlihat dari adanya pemilahan produksi antar generasi, bahkan cenderung ke antar individu. Fenomena tersebut jelas akan menyebabkan penduduk lanjut usia akan mengalami kesulitan dalam pemenuhan kebutuhan ekonomi.

Terpisahnya anak dari orang tuanya menurut Effendi \& Sukamdi (1994); Patmonodewo (2001) terjadi karena seorang anak yang menikah akan segera memisahkan diri dan hidup secara terpisah dengan orang tuanya. Keadaan ini membawa dua implikasi penting. Pertama, dengan perbaikan kondisi ekonomi, seorang anak yang sudah menikah akan cepat mandiri secara ekonomi. Artinya, keluarga besar (extended family) tidak lagi memainkan peranan ekonomi yang besar dalam keluarga. Akibatnya, anak lebih cepat independen dari orang tuanya. Kedua, orang tua akan segera ditinggalkan anak-anaknya, yang berarti dalam usia lanjut mereka akan hidup sendirian sehingga keluarga tidak lagi menjadi basis kekuatan yang menopang kesejahteraan lansia. Padahal lansia hidup tidak hanya butuh kecukupan ekonomi semata yang bisa dikrimkan anak-anaknya setiap saat, tetapi lansia juga sangat membutuhkan perhatian, kasih sayang, penghormatan, penghargaan dan pelayanan yang maksimal dari seorang anak yang pernah dilahirkannya. Bahkan, tidak jarang banyak lansia yang hidup sebatang kara dan tidak pernah mendapatkan perhatian, kasih sayang, penghormatan, penghargaan dan pelayanan yang maksimal dari seorang anak. Berpijak pada permasalahan tersebut maka dilakukan penelitian dilakukan dengan tujuan; (1) mengkaji dinamika proses perubahan socioculture dan economic separation yang terjadi pada keluarga lansia; (2) mengkaji kondisi kehidupan sosial-demografi dan ekonomi lansia dalam kondisi spatial separaton; dan (3) menganalisis pengaruh perubahan socio-culture dan economic separation anggota keluarga terhadap kehidupan lansia di Desa Tileng Kecamatan Girisubo Kabupaten Gunung Kidul.

\section{METODE PENELITIAN}

Penelitian ini dilakukan di Desa Tileng Kecamatan Girisubo Kabupaten Gunung Kidul. Populasi dalam 
penelitian ini adalah keluarga lansia, baik yang hidup sendiri maupun yang masih berpasangan suami-istri. Jumlah sampel yang diambil sebanyak 100 keluarga lansia yang ada di Desa Tileng Kecamatan Girisubo Kabupaten Gunungkidul. Respondennya adalah kepala keluarga lansia, sedangkan pengambilan sampel menggunakan metode simple random sampling. Data yang dikumpulkan dalam penelitian ini ada dua jenis yaitu data primer dan data sekunder. Data primer secara langsung dikumpulkan di lapangan melalui wawancara secara terstruktur dengan responden menggunakan kuesioner, sedangkan data sekunder dikumpulkan dari instansi pemerintah seperti, Badan Pusat Statistik (BPS), kantor desa dan pedukuhan serta instansi pemerintah lainnya.

Variabel yang digunakan dalam penelitian ini meliputi variabel sosial-demografi, ekonomi, socioculture, economic separation, culture separation dan aspek lainnya. Varibel socio-culture dan culture separation diukur dari aspek pendidikan anggota keluarga, tradisi dan adat istiadat dalam keluarga, budaya masyarakat dalam memperlakukan orang, status sosial keluarga di masyarakat, bentuk atau jenis hubungan sosial antara anak dan orang tua, sedangkan pengukuran variabel economic separation diukur dari aspek aktivitas ekonomi anggota keluarga, perubahan aktivitas ekonomi, bentuk bantuan ekonomi anggota keluarga, keragaman sumberaktivitas ekonomikeluarga, lokasi aktivitas ekonomi dan pendapatan. Sementara itu, untuk variabel spastial separation diukur dari lokasi tempat kerja atau tempat tinggal antara anggota keluarga dengan orang tua dan tahun mulai berpisah.

Pengukuran perubahan variabel socio-culture menggunakan skala likerts dengan pemberian skor. Untuk mengetahui arah kecenderungan perubahan socio-cuture menggunakan perhitungan metode kuartil. Metode kuartil (Q) adalah suatu metode yang membandingkan nilai skor yang diberoleh dari survei dengan nilai batas bawah, batas atas, kuartil 1 (Q1), kuartil 2 (Q2) dan kuartil 3 (Q3). Data yang telah ditabulasi kemudian ditampilkan baik dalam bentuk tabel frekuensi atau silang, grafik maupun gambar. Analisis data dilakukan secara deskriptif kualitatif dengan menggunakan tabel frekuensi dan tabel silang.

\section{HASIL DAN PEMBAHASAN \\ Kondisi Lokasi Penelitian}

Desa Tileng merupakan satu dari delapan desa di Kecamatan Girisubo, Kabupaten Gunung Kidul yang berada kurang lebih $5 \mathrm{Km}$ di sebelah utara pusat pemerintahan Kecamatan Girisubo atau sekitar 49 Km dari pusat pemerintahan Kabupaten Gunung kidul. Secara administratif Desa Tileng terbagi menjadi 16 dusun, 16 RT (Rukun Tetangga) dan 49 RW (Rukun Warga) dengan luas wilayah 1.699,8 ha atau sekitar $18,8 \%$ dari total luas Kecamatan Girisubo. Penggunaan lahan di Desa Tileng terdiri dari lahan pertanian kering seluas $1.080,40$ ha, lahan bangunan seluas 57,70 ha, lahan hutan rakyat seluas 464,0 ha dan lahan lainya seluas 97,7 ha, sedangkan perubahan penggunaan lahannya relatif sangat rendah.

Jumlah penduduk di Desa Tileng Pada Tahun 2017 tercatat sebanyak 4.494 jiwa yang terdiri dari 2.250 penduduk laki-laki dan 2.244 penduduk perempuan. Penduduk di Desa Tileng sebagian besar masih tergolong usia produktif yaitu mencapai 3.124 jiwa atau sekitar $69,5 \%$ sedangkan sisanya sebanyak 1.370 jiwa atau sekitar 30,9\% tergolong penduduk usia non produktif. Penduduk non produktif yang berumur $<15$ tahun tercatat sebanyak 642 atau sekitar 14,3\% sedangkan yang berumur $\geq 65$ tahun sebanyak 728 jiwa atau sekitar 16,2\% (Monografi Desa, 2017)). Penduduk usia produkif sebagian besar masih terkonsentrasi di sektor pertanian dengan produktivitas kerja yang relatif rendah. Hal ini terjadi karena aktivitas pertanian sangat tergantung pada lahan kering yang kurang produktif akibat tingginya ketergantungan pada sumber air hujan.

\section{Karakteristik Sosial-Demografi dan Ekonomi Keluarga Lansia}

Karakteristik sosial-demografi dan ekonomi keluarga lansia tercemin dari umur lansia, jumlah anak atau anggota keluarga, pendidikan lansia, pekerjaan utama dan pendapatan lansia. Hasil penelitian sebagaimana tercantum pada Tabel 1 menemukan rata-rata umur lansia di Desa Tileng adalah 76,3 tahun, sedangkan dilihat dari distribusnya tampak sebagian besar lansia berumur diantara 70-80 tahun yaitu mencapai 59,0\%, kemudian disusul dengan lansia yang berumur $>80$ tahun sebanyak $22,0 \%$, yang berumur antara 65-69 tahun sebanyak 12,0\% dan sisanya sebanyak $7,0 \%$ berumur $<65$ tahun. Jika dikaitkan dengan usia produktif tampak lansia yang masih masuk pada usia produktif hanya sebanyak 7,0\% saja dan sisanya sebanyak 93,0\% sudah tidak produktif. Fenomen ini memberikan gambaran bahwa lansia di lokasi penelitian sebagian besar masuk dalam kategori non produktif, tapi dalam kenyataannya masih banyak lansia yang masih aktif bekerja di pertanian yaitu sebanyak $86,0 \%$. Hal itu terjadi karena tidak adanya regenerasi petani yang dapat menggantikan petani, sehingga terpaksa para lansia masih bekerja di pertanian. Disamping itu, karena lansia tidak mau menggantungkan hidup pada anak-anaknya atau anggota keluarga lainnya.

Aspek sosial-demografi yang juga cukup menarik untuk dianalisis adalah anggota keluarga lansia. Anggota keluarga lansia dalam penelitian ini terdiri dari kepala keluarga, istri dan anak, baik yang masih tinggal serumah maupun tidak. Hasil penelitian sebagaimana tercantum pada Tabel 1. tampak rata-rata anggota keluarga lansia sebanyak 6 orang, sedangkan dilihat dari distribusinya tampak sebanyak 61,0\% lansia di lokasi penelitian memiliki anggota keluarga berkisar antara 5-6 orang, kemudian disusul lansia yang memiliki anggota keluarga $>6$ orang sebanyak $30,0 \%$ dan sisanya sebanyak $9,0 \%$ hanya memiliki 
anggota keluarga $<5$ orang. Fenomen ini dapat memberikan gambaran bahwa setiap keluarga lansia

Tabel 1. Karakteristik Sosio-Demografi Keluarga Lansia

\begin{tabular}{llll}
\hline $\begin{array}{l}\text { Kelompok } \\
\text { Umur Lansia }\end{array}$ & Frekuensi & Persentase \\
\hline 1. & $<65$ tahun & 7 & 7,0 \\
2. & $65-69$ tahun & 12 & 12,0 \\
3. & $70-80$ tahun & 59 & 59,0 \\
4. & $>80$ tahun & 22 & 22,0 \\
Total & 100 & 100,0 &
\end{tabular}

Rerata 76,3 tahun

Anggota Kelu- Frekuensi

Persentasi arga Lansia

1

2.

3.

Total

$<5$ orang

9

61

30

100,0

Rerata

6 orang

Tingkat Pen-

Frekuensi didikan Lansia

1

2.

3.

4.

Total

Pendapatan

$$
\mathrm{Ti}
$$

SD

SD

SLTP

SLTA

Lansia

1.

2.

3.

4.

Total

Rerata

Total

Pendapatan

Keluarga

Lansia

1.

2.

3.

Total

100

Frekuensi

Rp 0,-

$<$ Rp 500.000,-

Rp 500.000- $\quad 35$

1.000.000,-

$\mathrm{Rp}>1.000 .000,-19$

Persentase

23

72

4

1

100,0

Persentase

100

100,0

Rp 653.757,-

Frekuensi

Persentase

23,0

72,0

4,0

1,0

9,0

61,0

30,0

0

rata-rata memiliki jumlah anak sebanyak 4 orang. Walaupun jumlah anak lansia masih tergolong cukup banyak, namun hanya sebagian kecil saja yang tingal bersama satu rumah dengan lansia, sedangkan yang lainya ada yang hanya seatap tetapi berbeda dapur, bertetanggaan dengan anak-anaknya, satu RT/RW, satu dusun/desa/kecamatan, satu kabupaten/ provinsi dan ada yang berbeda kabupaten/provinsi/negara.

Aspek-sosial-demografi lainya yang juga menarik untuk dianalisis adalah tingkat pendidikan lansia. Hasil penelitian sebagimana tercantum pada Tabel 1 . menemukan pendidikan lansia sebagian besar masih didominasi tamat SD yaitu sebanyak $72,0 \%$ dan tidak tamat SD yaitu sebanyak 23,0\% sedangkan yang berpendidikan SLTP hanya sebanyak 4,0\% dan SLTA sebanyak 1,0\%. Fenomen ini memberikan gambaran bahwa generasilansia pada masa lalu belum menganggap penting akan pendidikan, sehingga banyak diantara lamsia yang masih beranggap tidak perlu sekolah sampai tinggi yang penting bisa baca tulis. Lain halnya, dengan generasi anak-anak lansia yang sudah mulai berubah pandangan terhadap pentingnya pendidikan dalam meningkat kualitas sumber daya manusia.

Aspek ekonomi yang cukup menarik untuk dianalisis pada keluarga lansia adalah pendapatan lansia dan total pendapatan keluarganya. Pendapatan lansia merupakan pendapatan yang di peroleh dari pekerjaan pokok maupun samping lansia yang berasal dari hasil pertanian maupun non pertanian. Hasil penelitian sebagimana tercantum pada Tabel 1. tampak ada sebanyak $14,0 \%$ kepala keluarga lansia yang pendapatannya $\mathrm{Rp}$ 0,- per bulan karena sudah tidak bekerja, sedangkan lansia yang masih bekerja rata-rata pendapatan yang diterimanya sebesar Rp 653.757,- per bulan. Fenomena ini memberikan gambaran bahwa lansia di lokasi penelitian sebagian besar memiliki pendapatan yang rendah, sehingga untuk memenuhi kebututuhan hidupnya sebagian harus dipenuhi dari anak-anaknya. Apalagi bagi lansia yang sudah tidak mampu bekerja untuk memenuhi kebutuhan hidupnya harus menggantunkan sepenuhnya pada anggota keluarganya. Hasil penelitian pada Tabel 1. tampak pendapatan lansia setelah mendapatkan remiten dari anak-anaknya ada peningkatan pendapatan yang terima lansia yaitu menjadi sebesar Rp 1.169.600,- per bulan.

\section{Dinamika Proses Perubahan Socio-culture pada Keluarga Lansia}

46,0

1.000.000,-

Rp 1.000.000- 26

1.500.000,-

$\mathrm{Rp}>1.500 .000,-\quad 28$

100,0

Rata-Rata

100

(Rp/bulan)

Rp 1.169.600,-
Dinamika proses perubahan socio-culture dalam keluarga lansia salah satunya tercermin dari adanya perubahan pendidikan anak-anak lansia yang jauh lebih baik dibandingkan dengan kedua orang tuanya. Pendidikan lansia sebagian besar masih di dominasi tamat SD dan tidak tamat SD sedangkan yang berpendidikan SLTP dan SLTA relatif masih sangat sedikit. Sebaliknya rata-rata pendidikan anak-anaknya sebagian besar telah berpendidikan SLTP, SLTA dan bahkan sudah ada yang berpendidikan diploma dan 
sarjana (Gambar 2). Perbedaan pendidikan tersebut mengakibatkan adanya perbedaan padangan dalam kehidupan socio-culture yang cukup tajam antara penduduk lansia dan usia muda. Akibatnya kehidupan lansia dan anggota keluargnya sulit untuk digabungkan dalam satu keluarga, sehingga terjadilah perubahan keluarga luas menjadi keluarga inti. Perubahan keluarga tersebut menyebabkan beberapa lansia hidup terpisah dari anggota keluarganya, sedangkan anak-anaknya membentuk keluarga baru. Perubahan status keluarga tersebut mengakibatkan beban sosial maupun ekonomi tidak lagi ditanggung bersama antara lansia dan anggota keluarganya. Bahkan, dalam keluarga inti tugas perawatan orang tua dikala lajut usia tidak lagi dilakukan oleh anak-anaknya, sehingga peran sosial anak diambil alih oleh orang lain. Jika fenomena tersebut yang terjadi maka lansia pada akhirnya bukan lagi menjadi bagian dalam satu keluarga karena terpisah jauh dari anak-anaknya.

Dinamika proses perubahan socio-culture dalam keluarga lansia juga dapat disebabkan karena adanya perubahan persepsi lansia terhadap nilai-nilai socioculture. Pada saat ini beberapa nilai-nilai socio-culture yang terpelihara dan mengikat dalam kehidupan lansia sudah mulai luntur sejalan dengan perkembangan jaman. Adapun nilai socio-culture yang semakin banyak ditinggalkan keluarga lasia di Desa Tileng diantaranya adalah terkait dengan; (1) konsep "mangan ora mangan sing penting kumpul" dalam keluarga dianggap sudah tidak jamannya lagi; (2) tidak melarang jika anak perempuan bekerja jauh dari orang tua; (3) tidak mewajibkan anak- harus mudik di setiap hari raya idul fitri atau hari raya lainnya; (4) anak perempuan memiliki hak yang sama untuk menempuh pendidikan tinggi (D3, S1, S2 atau S3); (5) anak laki-laki tidak lagi menjadi prioritas utama untuk menempuh pendidikan tinggi (D3, S1, S2 atau S3); (6) anak perempuan tidak boleh hanya bekerja di dapur dan mengurus anak-anak saja tetapi harus bekerja menghasilkan ekonomi; (7) baik anak laki maupun anak perempuan harus memiliki langkah panjang (berani merantau jauh) untuk bisa mendapat pekerjaan yang lebih baik; (8) tidak hanya anak laki-kali yang harus memiliki tanggungjawab ekonomi terhadap orang tua dikala lanjut usia; (9) tidak hanya anak perempuan yang harus memiliki tanggungjawab sosial (merawat dan menemani ) orang tua dikala lanjut usia dan (10) orang tua merasa iklas dan ridho jika harus hidup sendiri dikala lanjut usia. Persepsi lansia terhadap nilai-nilai socio-culture pada keluarga lansia dapat dilihat pada Gambar 1.

Hasil penelitian seperti yang tampak pada Gambar 1. menunjukkan nilai total sekor yang diperoleh dari responden sebesar 4.368. Nilai tersebut berada diantara kuartil 3 (Q3) dan batas atas (B), yang berarti mengarah kearah semakin banyak nilai-nilai socio-culture yang dianggap tidak lagi penting dan dipraktekan dalam keluarga lansia. Dengan semakin longgarnya persepsi lansia terhadap nilai socio-culture maka cukup beralasan jika semakin banyak lansia yang hidup terpisah dari anak-anaknya. Fenomena ini tentu harus menjadi perhatian agar proses perubahan socio-culture dalam keluarga lansia tidak menimbulkan masalah dalam kehidupan lansia dengan anggota keluarga yang terpisah. Perbedaan pendidikan lansia dan anggota keluarganya dapat dilihat pada Gambar 2. berikut

Hasil penelitian sebagiman tercantum pada Gambar 2. menunjukan pendidikan lansia sebagian besar masih di dominasi tamat SD yaitu sebanyak 72,0\% dan tidak tamat SD yaitu sebanyak 23,0\% sedangkan yang berpendidikan SLTP hanya sebanyak 4,0\% dan SLTA sebanyak1,0\%. Berbeda dengan anak-anak lansia yang sebagian besar telah mengenyang pendidikan SLTP, SLTA dan sebagian lagi berpendidikan SD, bahkan sudah ada yang berpendidikan diploma dan sarjana.

\section{Proses Terjadinya Economic Separation dan Spatial Separation pada Keluarga Lansia}

Proses terjadinya economic separatian antara lansia dengan anak-anaknya merupakan suatu proses terpisahnya pemenuhan kebutuhan ekonomi dalam keluarga karena adanya perubahan peran tanggungjawab dalam memenuhi kebutuhan ekonomi keluarga. Sementara itu, proses terjadinya spatial separation antara lansia dengan anak-anaknya merupakan suatau proses mulai terpisahnya antara lansia dengan anakanaknya kerana adanya perbedaan lokasi tempat kerja dan tinggal. Proses economic separation antara lansia dengan anak-anaknya pada awalnya dipicu dari adanya perubahan aktivitas

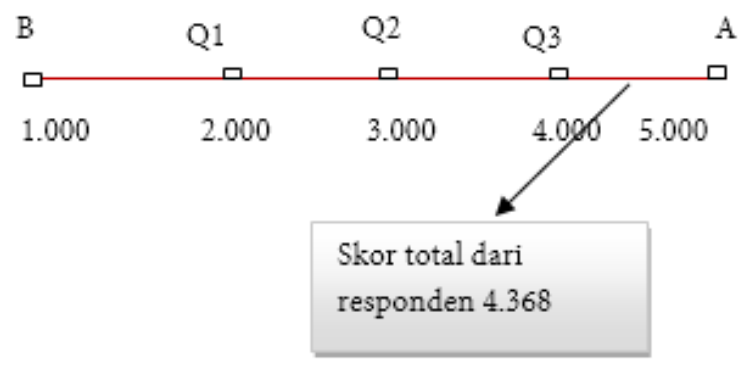

Gambar 1. Nilai Skror Batas Atas (A), Q1, Q2, Q3

Batas Bawah (B) dan Total Skor dari Responden

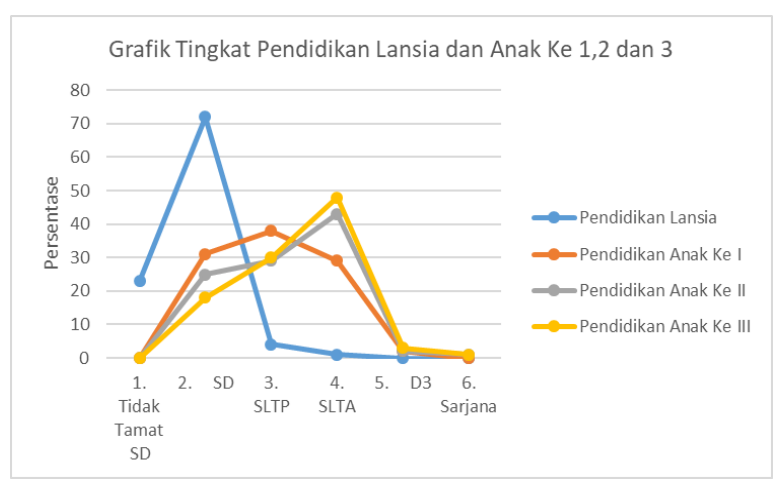

Gambar 2. Grafik Tingkat Pendidikan Lansia dan Anak-Anaknya 
ekonomi tradisional menjadi aktivitas ekonomi modern pada anak-anak lansia. Perubahan aktivitas ekonomi dalam keluarga lansia terjadi karena adanya perubahan pendidikan pada anak-anaknya, sehingga banyak anak dari keluarga lansia yang tidak menginginkan lagi aktivitas ekonomi tradisional. Bahkan, pada masyarakat modern, aktivitas ekonomi tradisional akan semakin berkurang sejalan dengan semakin berkurangnya peran orang tua dalam mewariskan aktivitas ekonomi tradisional. Oleh karena itu, cukup beralasan jika banyak orang tua berupaya untuk meningkatkan pendidikan anaknya agar kelak dikemudian hari mampu bersaing dan menyesuaikan diri untuk beraktivitas di ekonomi modern yang jauh lebih menjanjikan.

Perubahan pendidikan anak pada keluarga lansia juga akan membuka peluang anak untuk melakukan mobilitas vertikal maupun horisontal dalam rangka mencari aktivitas ekonomi modern yang lebih menjanjikan. Padahal aktivitas ekonomi modern sebagaian besar ada di perkotaaan yang jauh dari tempat tinggal asalnya, sehingga anak-anak lansia yang berpendidikan tinggi harus meninggalkan orang tuanya. Pada akhirnya keberhasilan anak-anak lansia di perkotaan mendapatkan pekerjaan dan penghasilan yang lebih baik menyebabkan munculnya economic separation antara lansia dengan anggota keluarganya. Para lansia akan tetap hidup dengan aktivitas ekonomi tradisional di daerah perdesaan, sedangkan anakanaknya akan hidup di aktivitas ekonomi modern yang jauh dari lokasi tempat asalnya. Karena tuntutan pekerjaan yang harus menetap di lokasi dekat tempat kerja dan keinginan anaknya membentuk keluarga baru maka proses terjadinya spatial separation antara lansia dengan anaknya tidak dapat dihindari lagi.

Proses terjadinya spatial separation antara lansia dengan anak-anaknya yang telah membentuk keluarga menurut Cowgill (1986) sering menjadi salah satu pemicu adanya perubahan sikap perilaku dan aspirasi generasi muda terhadap aspek-aspek sosial-cultur dan bahkan ekonominya. Akibatnya, para generasi muda akan memiliki rasa tanggung jawab rendah dalam menyantuni orang tuanya yang telah berusia lanjut di daerah asalnya. Bahkan, dilihat dari segi ekonomi ada kecenderungan untuk berubah, dari ekonomi keluarga yang bersifat a unit of production shared menjadi pemilahan produksi antargenerasi atau antarindividu. Gejala ini jelas akan menyebabkan para lansia yang ditinggalkan anak-anaknya akan mengalami kesulitan dalam ekonomi, kerana mereka harus menanggung ekonomi sendiri dengan segala keterbatasnya. Awal proses terjadinya spatial separation antara lansia dengan anak ke 1, 2 dan ke 3 digambarkan pada Gambar 3.

Hasil penelitian sebagaimana tercantum pada Gambar 3. menunjukkan adanya variasi tahun awal terjadinya proses spatial separation antara lansia dengan anak-anaknya yang memicu munculnya economic separation. Proses terjadinya spatial separation pada anak pertama lebih banyak terjadi antara tahun 1980-
1990 yaitu sebanyak 51,0\%, kemudian disusul antara tahun 1991-2000 yaitu sebanyak 29,0\%, kemudian antara tahun 1950-1980 sebanyak 13,0\% dan sisanya sebanyak 7,0\% antara tahun 2001-2016. Pada anak kedua proses terjadinya spatial separation lebih banyak terjadi antara tahun 1980-1990 yaitu sebanyak 44,0\%, kemudian antara tahun 1991-2000 yaitu sebanyak $32,0 \%$, antara tahun 2001-2016 sebanyak 18,0\% dan sisanya sebanyak 6,0\% antara tahun 1950-1980. Sebaliknya pada anak ketiga proses terjadinya spatial separation lebih banyak terjadi antara tahun 1991-2000 yaitu sebanyak 53,0\%, kemudia antara tahun 2001-2016 sebanyak 32,0\%, antara tahun 1980-1990 sebanyak $13,0 \%$ dan sisanya sebanyak 2,0\% antara tahun 19501980. Adapun yang menjadi alasan anak mulai tidak tinggal serumah (spatial separation) pada keluarga lansia di Desa Tileng dapat dilihat pada Gambar 4.

Hasil penelitian pada Gambar 4. menemukan adanya variasi alasan anak mulai tidak tinggal serumah (spatial separation) dengan lansia. Pada anak pertama alasan yang paling dominan mulai terjadinya spatial separation dikarenakan anak berkeluarga dan ikut suami/istri yaitu sebanyak 64,0\%, kemudian karena berkerja sebanyak 32,0\%, karena kuliah dan transmigrasi masing-masing sebanyak 2,0\%. Untuk anak kedua alasan yang paling dominan adalah karena alasan bekerja yaitu mencapai 60,0\%, kemudian berkeluarga dan ikut suami/istri sebanyak 37,0\% dan kuliah sebanyak 3,0\%. Pada yang ketiga alasan yang paling dominan adalah alasan karena bekerja mencapai

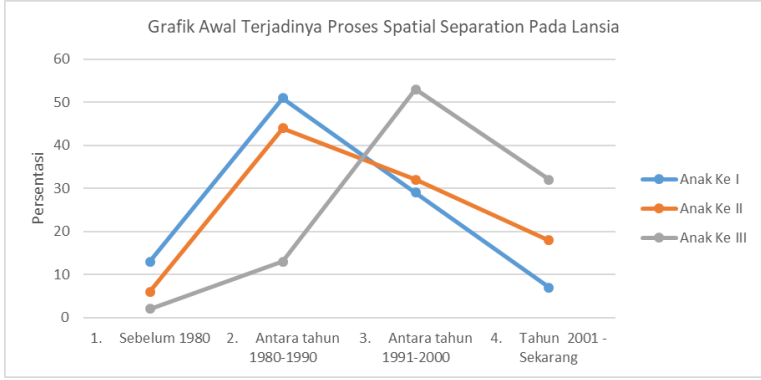

Gambar 3. Grafik Awal Proses Terjadinya Spatial Separation

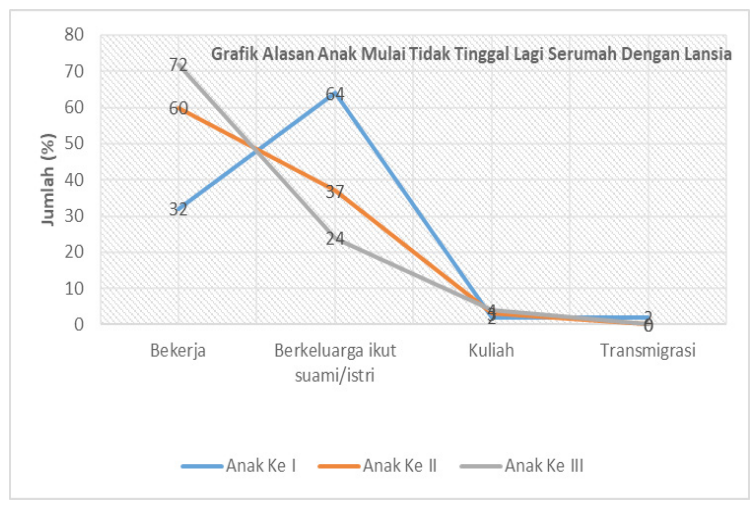

Gambar 4. Grafik Alasan Anak Ke 1, 2 dan 3 Mulai Tidak Tinggal Serumah Dengan Lansia 
72,0\%, kemudian disusul alasan berkeluarga dan ikut suami/istri sebanyak $24,0 \%$ dan sisanya alasan karena kualiah sebanyak 4,0\%. Jika dilihat secara keseluruhan tampak bahwa proses terjadinya spatial separation yang memicu munculnya separation economic antara lansia dengan anggota keluarganya lebih banyak disebabkan karena alasan bekerja yang jauh dari lokasi tempat tinggal. Adapun lokasi tempat bekerja dan tempat tinggal anak keluarga lansia dapat dilihat Gambar 5a., 5b. dan 5c.

Hasil penelitian pada Gambar 5a., 5b. dan 5c. menunjukkan lokasi tempat kerja sekaligus tempat tinggal anak keluarga lansia menyebar di beberapa kota di Jawa dan di luar Jawa. Pada anak ke satu lokasi tempat kerja sekaligus tempat tinggalnya banyak ditemukan di Jakarta yaitu sebanyak 23,0\%, kemudian di Desa Tileng yang merupakan tempat tinggal orang tuanya sebanyak $21,0 \%$ sedangkan yang lainya menyebar baik di Jawa dan di luar Jawa. Demikian juga pada anak ke kedua,

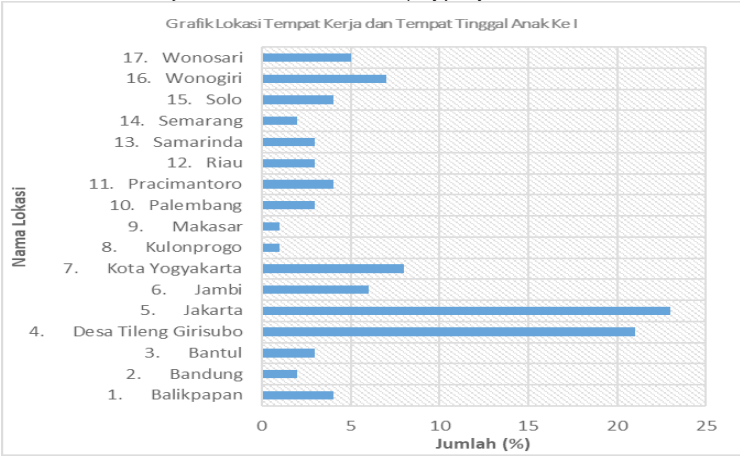

Gambar 5a. Grafik Lokasi Tempat Kerja dan Tempat Tinggal Anak Ke I

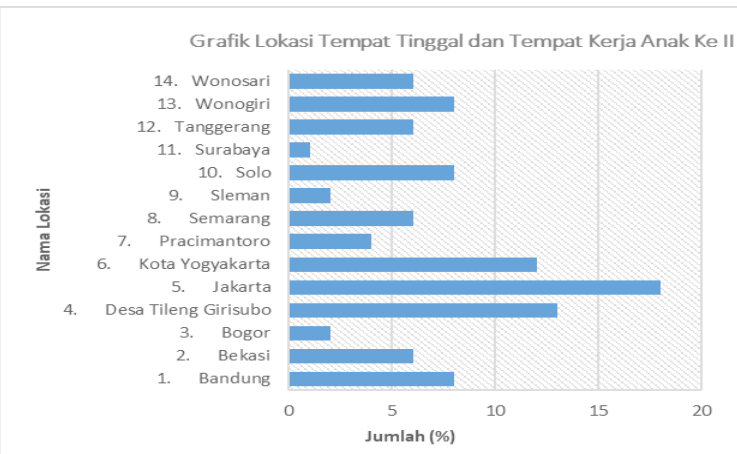

Gambar 5b. Grafik Lokasi Tempat Kerja dan Tempat Tinggal Anak Ke II

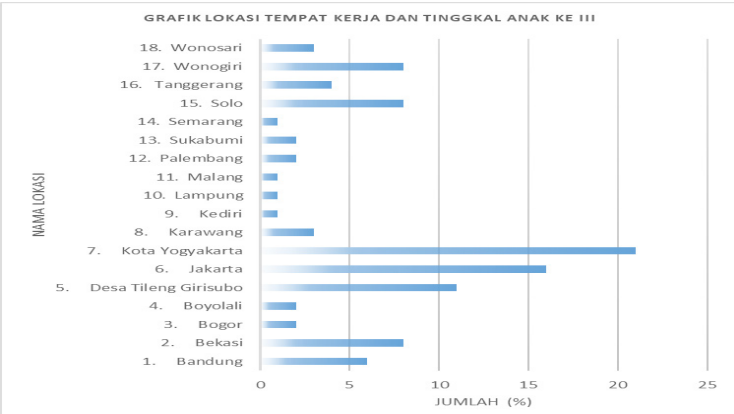

Gambar 5c. Grafik Lokasi Tempat Kerja dan Tempat Tinggal Anak Ke III banyak ditemukan di Jakarta yaitu sebanyak 18,0\%, kemudian di Desa Tileng sebanyak 13,0\%, kemudian di Kota Yogyakarta sebanyak 12,0\% dan di kota lainya yang tersebar di wilayah Jawa, sedangkan yang merantau ke luar Jawa tidak ditemukan. Sementara itu, pada anak ketiga lebih banyak ditemukan di Kota Yogyakarta yaitu sebanyak $21,0 \%$, kemudian di Jakarta sebanyak $16,0 \%$, di Desa Tileng sebanyak 11,0\% dan yang lainya tersebar di beberapa kota di Jawa dan sebagian di luar Jawa. Fenomen ini memberikan gambaran bahwa proses spatial separation antara lansia dan anggota keluarga terjadi karena perbedaan tempat kerja dan tempat tinggalnya. Perbedaan lokasi tersebut pada akhirnya memicu munculnya economic separation yang menyebabkan lansia harus mengurus ekonomi sendiri yang terpisah dari anggota keluarganya.

\section{Pengaruh Perubahan Socio-culture dan Economic Separation terhadap Kehidupan Lansia}

Perubahan socio-culture dan munculnya economic separation dalam keluarga lansia telah menyebabkan terjadinya perubahan kehidupan lansia. Kehidupan lansia dalam kondisi economic separation seperti halnya manusia biasa memiliki kebutuhan hidup yang sama dengan penduduk usia muda agar dapat hidup sejahtera. Adapun kebutuhan hidup lansia diantaranya adalah; kebutuhan akan makanan bergizi seimbang, pemeriksaan kesehatan secara rutin, perumahan yang sehat dan kondisi rumah yang tentram dan aman, kebutuhan-kebutuhan sosial seperti bersosialisasi dalam bentuk berkomunikasi, membagi pengalaman dan memberikan pengarahan untuk kehidupan yang baik. Hasil penelitian terkait dengan kebutuhan lansia dapat dilihat pada Gambar 6 .

Hasil penelitian seperti yang tercantum pada Gambar 6. menunjukkan ada sebanyak 45,0\% untuk pemenuhan kebutuhan makan dan minum dipenuhi lansia sendiri dan sisanya sebanyak 55,0\% dipenuhi dari anggota keluarganya. Untuk pemenuhan kebutuhan biaya berobat/iuran BPJS dan pembayaran pajak bumi dan bangunan semuanya dibiaya dari anak-anak lansia, sedangkan untuk pemenuhan kebutuhan sosial ditemukan sebanyak 48,0\% dipenuhi lansia dan sisanya sebanyak 52,0\% dipenuhi anak-

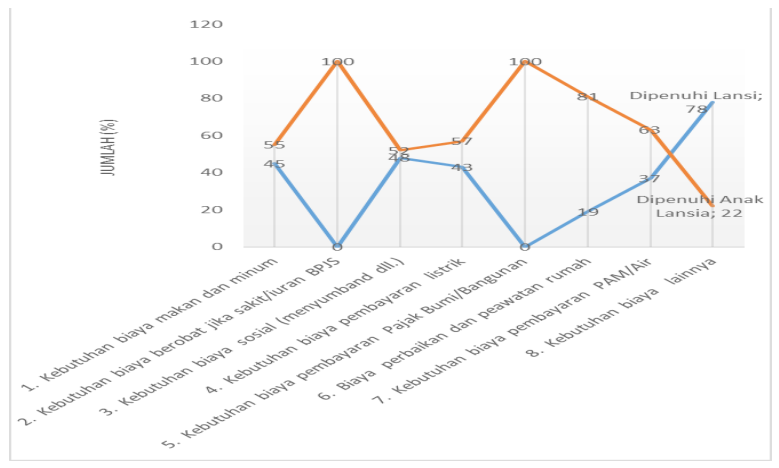

Gambar 6. Grafik Jenis Kebutuhan Ekonomi dan Cara Lansia Memenuhinya 
anaknya. Untuk pemenuhan kebutuhan biaya listrik ditemukan sebanyak 43,0\% dipenuhi lansia dan sisanya sebanyak $57,0 \%$ dipenuhi anggota keluarganya, sedangkan pemenuhan kebutuhan biaya perbaikan dan perawatan rumah ditemukan sebanyak 19,0\% dipenuhi lansia dan sisanya sebanyak $81,0 \%$ dipenuhi anak-anaknya. Untuk pemenuhan kebutuhan air PAM ditemukan sebanyak 37,0\% dipenuhi lansia dan sisanya sebanyak $63,0 \%$ dipenuhi anggota keluarganya, sedangkan untuk kebutuhan lainya ditemukan sebanyak 78,0\% dipenuhi lansia dan sisanya sebanyak $22,0 \%$ dipenuhi anggota keluarganya yang berasal dari anak kesatu, kedua, ketiga dan seterusnya.

Bantuan yang diberikan anak kepada lansia cukup beragam, seperti pakaian, alat sholat, makan dan minuman serta barang lainnya, tetapi ada juga yang memberikan dalam bentuk uang secara rutin. Pemberian barang maupun uang ada yang rutin tiap bulan, tetapi ada juga yang hanya saat pulang mudik di hari raya idul fitri atau idul adha atau hari raya lainnya. Namun demikian, menurut lansia ada juga anaknya yang jarang memberikan barang maupun uang secara rutin, namun jika diminta bantuan untuk menutupi keperluan yang mendesak suka memberikan juga. Besarnya ratarata remiten yang diterima lansia setiap bulannya dari anak-anaknya dapat dilihat pada Gambar 7.

Hasil penelitian sebagaimana tercantum pada Gambar 7. menunjukkan total remitan yang diterima lansia dari seluruh anak setiap bulannya rata-rata $\mathrm{Rp}$ 509.495,-. Jika dilihat dari sebarannya tampak sebagian besar remitan yang diterima lansia setiap bulanya $\mathrm{Rp}<$ 750.00 ,- yaitu sebanyak $81,0 \%$, kemudian disusul yang menerima remiten antara Rp 750.000-1.000.000,- per bulan sebanyak $11,0 \%$, yang menerima remiten antara Rp 1.000.000-1.500.000,- per bulan sebanyak 6,0\%, sedangkan yang menerima remiten $\mathrm{Rp}>1.500 .000$,- per bulan hanya sebanyak $2,0 \%$. Fenomen ini menunjukkan bahwa total remiten yag diterima lansia setiap bulan cukup bervariasi. Hal ini terjadi karena remiten yang diterima lansia setiap bulanya tidak selalu sama, baik dari sisi waktu pengiriman maupun dari besar uang yang dikirimkan antara anak yang satu dengan anakyang lain.

Demikian juga, dengan jenis barang yang diterima lansia dari anggota keluarganya (anak) cukup

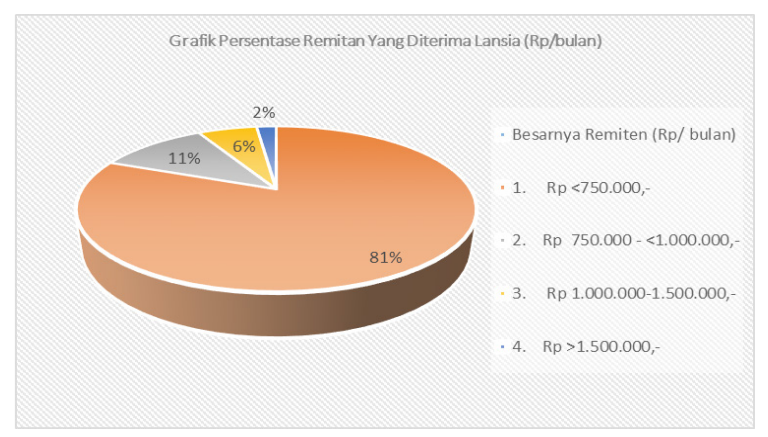

Gambar 7. Grafik Total Besarnya Remiten (kiriman) Yang Diterima Lansia bervariasi. Menurut beberapa lansia barang diterima lansia dari anggota keluarganya sebagian besar diterima pada hari-raya idul fitri, tahun baru dan natal atau pada acara tertentu. Adapun jenis barang yang pernah diterima lansia diantaranya adalah baju, celana, ruku/ mukena, peci, sarung, jarik, makanan dan minuman, alat elektronik, handphon, alat transportasi (sepeda/ sepeda motor) dan lainnya. Menurut lansia jenis barang yang diterima tersebut ada yang rutin diterima setiap tahun sekali, tetapi ada juga yang diterima hanya sekali dan tidak semua lansia menerimanya seperti; barang elektronika, alat komunikasi dan alat transportasi. Secara lebih rinci jenis barang yang diterima lansia dapat dilihat pada Gambar 8.

Kondisi kehidupan lansia sama seperti manusia lainnya ada yang merasa kecukupan baik dari hasil usaha sendiri maupun bantuan dari anggota keluarganya, tetap ada juga yang mengalami kekurangan pada saat tertentu. Secara lebih rinci upaya lansia dalam menutupi kekurangan untuk memenuhi kebutuhan hidup di Desa Tileng dapat dilihat pada Tabel 2.

Tabel 2. Upaya Lansia Dalam Memenuhi Kebutuhan Hidup

\begin{tabular}{lll}
\hline $\begin{array}{l}\text { Upaya Lansia Untuk } \\
\text { Memenuhi Kebutuhan } \\
\text { Hidup }\end{array}$ & Ferekuensi & Persentase \\
\hline $\begin{array}{l}\text { A.Tidak Pernah Merasa } \\
\text { Kekurangan (Tidak }\end{array}$ & 39 & 39.0 \\
$\begin{array}{l}\text { Pernah Meminta/ } \\
\text { Meminjam ) }\end{array}$ & & \\
Jumlah A & 39 & 100,0 \\
1. Pinjam Anak & 17 & 27,9 \\
2. Minta Anak & 24 & 39,4 \\
3. Pinjam Saudara & 13 & 21,2 \\
4. Pinjam Tetangga & 4 & 6,6 \\
5. Pinjam Bank/ Kop- & 1 & 1,6 \\
erasi & & \\
6. Lainnya & 2 & 3,3 \\
Jumlah B & 61 & 100.0 \\
Total A+B & 100 & 100,0 \\
\hline
\end{tabular}

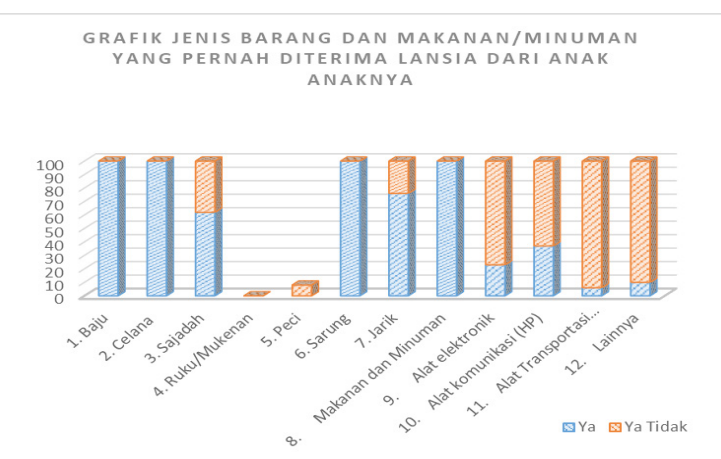

Gambar 8. Grafik Jenis Barang dan Makanan dan Minuman Yang Pernah Diterima Lansia

https://jurnal.ugm.ac.id/mgi|76 
Hasil penelitian pada Tabel 2. menemukan sebanyak 39,0\% keluarga lansia tidak pernah merasakan kekurangan dan sisanya sebanyak $61,0 \%$ keluarga lansia pernah merasakan kekurangan ekonomi, sehingga untuk menutupi kekurangnya harus meminjam atau meminta bantuan anggota keluarganya atau orang lain. Dari 61,0\% keluarga lansia yang pernah merasakan kekurangan untuk memenuhi kebutuhan hidup, diantaranya sebanyak $27,9 \%$ pernah meminjam kepada anak, sebanyak 39,4\% meminta pada anak, sebanyak $21,2 \%$ meminjam tetangga, sebanyak 6,6\% meminjam bank atau koperasi dan lainnya sebanyak 2,0\%. Fenomena ini memberikan gambaran bahwa kehidupan lansia dalam kondisi spatial separation dan economic separation dengan anggota keluarga masih banyak yang mengalami kekurangan untuk memenuhi kebutuhan hidupnya.

Perasaan lansia dalam kondisi spatial separation dan economic separation dengan anggota keluarganya adanya yang merasa kesepian, sedih, biasa aja, kangen cucu dan lain sebaginya. Secar lebih rinci hasil penelitian terkait dengan perasaan lansia dapat dilihat pada Gambar 9.

Hasil penelitian pada Gambar 9. menemukan bahwa kehidupan lansia setelah terpisah dengan anggota keluarganya, ada yang merasa sedih karena tidak bisa kumpul bersama lagi sebanyak $29,0 \%$, ada yang merasa biasa saja sebanyak $18,0 \%$, ada yang merasa sepi karena tidak ada anak cucu sebanyak 24,0\%, ada yang marasa takut anaknya hidup kekurangan sebanyak $10,0 \%$, ada yang merasa kesepian dan rindu pada anak sebanyak 14,0\% dan ada yang merasa cemas sebanyak 5,0\%. Fenomena ini cukup beralasan karena anggota keluarganya lansia sebagian besar merantau jauh dan frekuensi pulang kampung untuk bertemu dengan lansia sangat jarang. Bahkan ada juga yang sudah beberapa tahun tidak ketemu karena ada di luar Jawa dan jarang pulang.

Kehidupan lansia tidak terlepas juga dari harapan atas kesuksesan anggota keluarganya yang merantau maupun yang masih tinggal dalam satu desa. Hasil penelitian yang terkait dengan harapan lansia dapat dilihat pada Tabel 3.

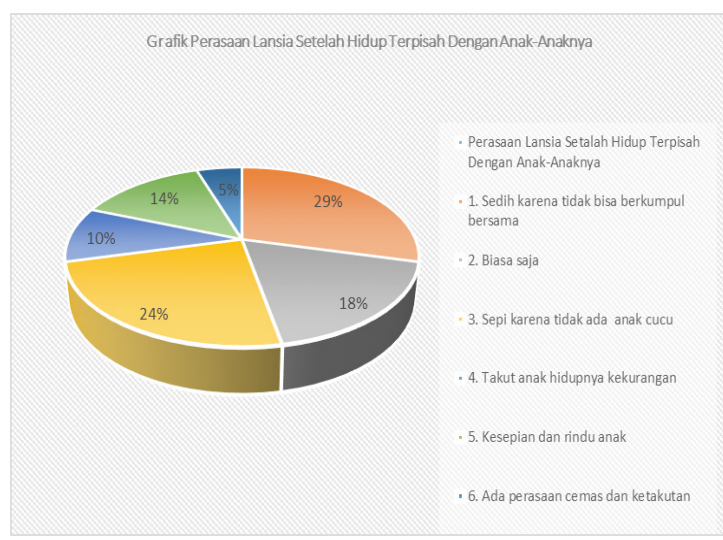

Gambar 9. Grafik Perasaan Lansia terhadap Anak-Anaknya
Tabel 3. Harapan Lansia pada Anggota Keluarganya

Harapan Lansia terhadap Frekuensi Persentase Anak-Anaknya

\begin{tabular}{llc}
\hline $\begin{array}{l}\text { Jika anak sukses ingin } \\
\text { dijamin sepenuhnya oleh } \\
\text { anak }\end{array}$ & 18 & 18.0 \\
$\begin{array}{l}\text { Selalu dikunjungi wa- } \\
\text { laupun datang dengan } \\
\text { tangan hampa }\end{array}$ & 22 & 22.0 \\
$\begin{array}{l}\text { Ingin selalu diperhatikan } \\
\text { dan disayangi anak }\end{array}$ & 24 & 24.0 \\
$\begin{array}{l}\text { Ketika sakit ingin } \\
\text { diperhatikan dan segera } \\
\text { ditengok }\end{array}$ & 13 & 13.0 \\
$\begin{array}{l}\text { Ingin tinggal bersama } \\
\text { anak-anak }\end{array}$ & 2 & \\
$\begin{array}{l}\text { Ingin melihat anak-anak- } \\
\text { nya bahagia }\end{array}$ & 6 & 2.0 \\
$\begin{array}{l}\text { Ingin melihat anak-anak- } \\
\text { nya sukses dirantau }\end{array}$ & 4 & 6.0 \\
$\begin{array}{l}\text { Ingin anak-anak hidup } \\
\text { rukun }\end{array}$ & 7 & 4.0 \\
$\begin{array}{l}\text { Ingin ada yang kembali ke } \\
\text { desa tinggal bersama }\end{array}$ & 4 & 7.0 \\
$\begin{array}{l}\text { Total } \\
\text { Sumber: Data Primer, } 2018\end{array}$ & 100 & 100.0 \\
\hline
\end{tabular}

Sumber: Data Primer, 2018

Hasil penelitian pada Tabel 3. menemukan ada beberapa harapan lansia terhadap anggota keluarganya diantaranya adalah jika anak sukses ingin dijamin kehidupannya oleh anak-anaknya sebanyak 18,0\%, ingin selalu dikunjungi anak-anaknya walaupun datang dengan tangan hampa ada sebanyak 22,0\%, ingin selalu diperhatikan dan disanyangi anak-anaknya sebanyak 24,0\%, ketika sakit ingin diperhatikan dan segera ditengok anak-anaknya sebanyak 13,0\%, jika sukses anak-anaknya ingin tinggal bersama sebanyak 2,0\%, ingin meliahat anak-anaknya bahagia ada sebanyak 6,0\%, Ingin melihat anak-anaknya sukses dirantau sebanyak $4,0 \%$, ingin anak-anaknya hidup rukun sebanyak 7,0\%, dan ingin ada anakanaknya yang kembali ke desa asal sebanyak 4,0\%.

\section{KESIMPULAN}

Proses perubahan socio-culture pada keluarga lansia tercermin adanya perubahan pendidikan anggota keluarga yang lebih baik dan perubahan padangan lansia terhadap nilai-nilai socio-culture yang dulu terpelihara dan terjaga di lingkungan masyarakatnya, sedangkan proses economic separation tercermin dari perubahan aktivitas ekonomi tradsional ke aktivitas ekonomi modern oleh anggota keluarganya karena adanya peningkatan pendidikan. Kondisi kehidupan lansia yang tercemin dari kondisi sosial-demografi dan ekonomi dalam kondisi spatial separation cukup 
beragam dan dipengaruhi oleh perubahan socioculture dan economic separation anggota keluarganya.

\section{UCAPAN TERIMA KASIH}

Pada kesempatan ini penulis mengucapkan banyak terima kasih kepada Program Studi S2 Kepedudukan yang telah memberikan dana Penelitian Hibah Bersaing Sekolah Pascasarjan UGM Tahun 2018. Penulis juga, mengucapkan banyak terima kasih kepada Anggota Tim Peneliti yang telah berperan dalam penulisan laporan hibah maupun naskah jurnal. Tidak lupa penulis juga mengucapkan terimaksih kepada Asisten Lapangan yang telah membantu dalam mengumpulkan data di lapangan.

\section{DAFTAR PUSTAKA}

Affandi, M. (2009). Faktor-Faktor Yang Mempengaruhi Penduduk Lanjut Usia Memilih Untuk Bekerja. Journal of Indonesian Applied Economics, Vol, 3 (2), 99-110. Andini, Ni, K., Desak, P.E.N., \& Made, S. (2013). FaktorFaktor Yang Mepengaruhi Penduduk Lanjut Usia Masih Bekerja. Piramida Jurnal Kependudukan dan Pengembangan Sumber Daya Manusia, IX(1), 44- 49.

Arini,I.A.,(2001).DampakSosial,EkonomiDinamikaMobilitas Penduduk Propinsi Bali (Sebelum dan Sesudah Krisis Moneter). Majalah Geografi Indonesia, 15(2), 149-163.

Badan Pusat Statistik. (2016). Propinsi DIY Dalam Angka. Yogyakarta: BPS.

Badan Pusat Statistik. (2016). Kabupaten Gunungkidul Dalam Angka. Gunungkidul: BPS.

Badan Pusat Statistik. (2010). Statistik Penduduk Lansia Indonesia: Hasil Sensus 2010. Jakarta: BPS.

Badan Koordinasi Kelurga Berencana. (1998). Penduduk Usia Lanjut. Jakarta: BKKBN.

Cowgill, D.O. (1986). Aging and Modernization. New York: Appleton.

Direktorat Jenderal Rehabilitasi Sosial. (2013). Pengembangan Metode dan Penguatan Pelayanan Sosial Lanjut Usia di Provinsi Daerah Istimewa Yogyakarta. Yogyarakta: Dirjen Rehabilitas Sosial. Effendi,S., \&Sukamdi.(1994). Perubahan Strukturdan peranan keluarga Dalam PJP II, Majalah Populasi. 5(1), 32-40. Ehrenberg, R.G., \& Smith, R.S. (1987). Comparable worth in the public sector (Electronic version). In D. A. Wise (Ed.): Public sector payrolls.

Junaedi. (2007). Peranan Keluarga Dalam Pemeliharaan Penduduk Lanjut Usia. Diakses Tanggal 13 April 2017 dari https://www.junaidichaniago.wordpress.com..

Kartikasari, D., \& Fitria H. (2012). Pemenuhan Kebutuhan Dasar Manusia Pada Lansia Demensia Oleh Keluarga. Jurnal Nursing Studies. 1(1), 175-182.

Kementrian Kesehatan Indonesia. (2017). Analisis Lansia di Indonesia. Jakarta: Pusat Data Informasi: Kemenkes Republik Indonesia.

Kementrian Kesehatan Indonesia. (2018). Jumlah Lansia Sehat Harus Meningkat. Jakarta: Kemenkes Republik Indonesia.

Maslow, A.H. (2007). Motivasi dan Kepribadian. Jakarta: Penerbit Pustaka Binaman Pressindo. Monografi Desa. 2017. Profil Desa Tileng. Kantor Desa Tileng. Patmonodewo S. (2001). Psikologi Perkembangan Pribadi Dari Bayi Sampai Lanjut Usia. Jakarta. UI Press.

Pepe, C., Kristika, H.K., Dessy, H.S.A. \& Meilanny, B.S. (2014). Dukungan Sosial Keluarga Dalam Memenuhi Kebutuhan Sosial Lansia di Panti. Social Work Jurnal. 7(1), 33-38.

Ninda, A., Prabasari P., Linda, J., \& Ira A.M. (2017). Pengalaman Keluarga Dalam Merawat Lansia di Rumah (Studi Fenomenologi), Jurnal Ners Lentera. (5)1, 56-68.

Ningrum, T.P., Okatiranti O., \& Desak, K.K.W. (2017). Hubungan Dukungan Keluarga Dengan Kualitas Hidup Lansia (Studi Kasus: di Kelurahan Sukamiskin Kota Bandung), Jurnal Keperawatan, Vol. 5(20), 83-88. Sarmita, I.M., S.R., Giyarsih, \& Umi, L. (2014). Niat Migrasi dan Penyesuaian Diri Migran Sirkuler Asal Jawa di Kecamatan KutaSelatan, Bali, Majalah GeografiIndonesia, (28)1,4-28.

Watson, R. (2003). Perawatan Pada Lansia, Jakarta: Published Egc. WHO. (2003). Technical paper: Health care of the elderly in the Eastern Mediterranean Region. Challenges and Perspectives.

Yuliani, T., \& Novita, S. (2014). Determinan Pembangunan Manusia Di Kabupaten/Kota Provinsi Jawa Tengah. Jejak Journal of Economics and Policy. (7)1, 60-72. 